\title{
AMBIGUOUS ADJECTIVES IN FRENCH: THE CASE OF "GROS" WHEN COMBINED WITH DEVERBAL NOUNS
}

\section{INTRODUCTION}

The problem of adjectival ambiguity is well-known, and many formal semanticists have tried to account for it since the early days of the discipline (Siegel 1976; Larson 1998). The fact that adjectives can have different readings depending on their position within the DP (for example, prenominal or postnominal) has also been analysed (see Cinque 2010, among others).

In this paper, I will focus on the adjective gros in French ("big", "fat"). This adjective is not interpreted in the same way when it appears before or after an -eur deverbal noun (see the examples in (1)).

(1)
a) Un gros fumeur
a GROS smoker
$\checkmark$ 'A heavy smoker'
?'A fat smoker'

b) Un fumeur gros

a smoker GROs

* 'A heavy smoker'

$\checkmark$ 'A fat smoker'

My goal is to explain the French facts by giving a compositional analysis of the phenomenon presented in (1). In the literature, two sources have been diagnosed in the literature for the ambiguity of DPs: the first is the adjective ("blame Adj", see Siegel 1976; Despić and Sharvit 2008), the second the noun ("blame NP", see Larson 1998). I will propose that another option, namely, "blame both", accounts for the French data better.

The paper is outlined as follows. In section 1, I present the standard classification of adjectives into at least intersective modifiers and non-intersective modifiers. Then I discuss data from French, demonstrating the ambiguity of the adjective "gros", and give generalisations that can be drawn from the data. In section 2, I review three previous analyses of ambiguous adjectives (Siegel 1976; Larson 1998; Winter and Zwarts 2012a,b). In section 3, I propose an analysis for DPs containing a deverbal noun and the adjective "gros" (both in the pre- and the postnominal position). The conclusion is concerned with open issues and further research.

* lucastual@unige.ch 


\section{AMBIGUOUS ADJECTIVES}

\subsection{Classification of Adjectives}

One possible classification of adjectives (see Partee 1995, a.o.) divides them into two categories: intersective (such as "red"), and non-intersective (such as "skillful"). The non-intersective class is often also subdivided into other categories (plain non-subsective, privative non-subsective, see Kamp and Partee 1995), but this fine-grained classification has been refuted, notably by Partee (2010). For the purposes of this paper, the distinction between intersective and non-intersective modifiers is sufficient, and thus I will not consider subdivisions of the non-intersective category.

When an adjective is intersective, as is the case with red, the denotation of an NP containing a noun and this kind of adjective is the intersection of the semantic value of the noun and the semantic value of the adjective, as described formally in (2).

(2) $\left[\left[\operatorname{Adj}_{\text {intersective }}\right.\right.$ Noun $\left.]\right]=\left[\left[\operatorname{Adj}_{\text {intersective }}\right]\right] \cap[[$ Noun $]]$

In a case such as (2), it is possible to say that everything that is an " $A d j_{\text {intersective }} N o u n$ "

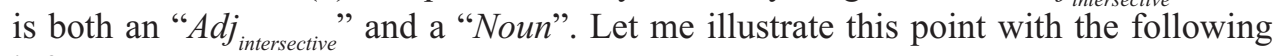
inference:

(3) This is a red table.

a) $\rightarrow$ This is a table.

b) $\rightarrow$ This is red.

Non-intersective adjectives do not follow the pattern just presented. A classic example of a non-intersective adjective is "skillful". If we reproduce the inference in (3) with the adjective "skillful", the entailment pattern is not similar:

(4) This man is a skillful surgeon.

a) $\rightarrow$ This man is a surgeon.

b) $\rightarrow$ This man is skillful.

Informally speaking, it is possible to say that someone is skillful as a surgeon, but that does not entail that this person is skillful in general. Hence, the right way to describe a non-intersective adjective is to say that the denotation of a NP containing a noun and a non-intersective adjective is not the intersection of the semantic value of the noun and the semantic value of the adjective:

$$
\left[\left[\operatorname{Adj}_{\text {non-intersective }} N \text { Noun }\right]\right] \neq\left[\left[\operatorname{Adj}_{\text {non-intersective }}\right]\right] \cap[[\mathrm{Noun}]]
$$

These kind of adjectives can be seen as having a more complex semantic type than intersective adjectives.

Having discussed the standard classification of adjectives, I will now present novel French data in which a specific adjective is ambiguous between an intersective and a non-intersective reading. 


\subsection{The French Data}

The French data presented in this section will be analysed in section 3. I will describe the interaction between the adjective "gros" and an -eur deverbal noun. (6-9) demonstrates that the interpretation of a DP containing both of these elements depends on whether or not the adjective is in the prenominal or the postnominal position.

(6) a) Un gros fumeur

a GROS smoker

$\checkmark$ 'A heavy smoker'

? 'A fat smoker'

(7) a) Un gros dormeur

a GROS sleeper

$\checkmark$ 'Someone who sleeps a lot'

? 'A fat sleeper'

(8) a) Un gros buveur

a GROS drinker

$\checkmark$ 'A heavy drinker'

? 'A fat drinker'

(9) a) Un gros mangeur

a GROs eater

$\checkmark$ 'A big eater'

? 'A fat eater' b) Un fumeur gros

a smoker GROS

* 'A heavy smoker'

$\checkmark$ 'A fat smoker'

b) Un dormeur gros

a sleeper GROS

* 'Someone who sleeps a lot'

$\checkmark$ 'A fat sleeper'

b) Un buveur gros

a drinker GROS

'A heavy drinker'

$\checkmark$ 'A fat drinker'

b) Un mangeur gros

a eater GROS

* 'A big eater'

$\checkmark$ 'A fat eater'

In all of the $a$ ) examples, the DP has a strongly preferred non-intersective reading: "un gros fumeur" will refer to a person who smokes a lot. Under this reading, the adjective is truly non-intersective, as is demonstrated by the failed entailment pattern in (10).

(10) Cet homme est gros fumeur.

This man is GROS smoker

a. $\rightarrow$ Cet homme est fumeur. this man is smoker

b. $\nrightarrow$ Cet homme est gros.

this man is fat

It is nonetheless possible to give an intersective interpretation to this kind of sentence, where "un gros fumeur" would refer to a person who smokes and who is fat. ${ }^{1}$ However, when this very same adjective is in a postnominal position (see the $b$ ) examples), the DP only bears an intersective reading, where "gros" means "fat".

Until now, I have only considered the interpretation of the adjective gros when it is used attributively. Let us consider now the use of this adjective in predicative constructions. (11) demonstrates that it only has an intersective reading.

1 The "?" next to the second free translation in a) examples states that the preferred reading when the adjective is prenominal is the non-intersective one. 
(11) Ce fumeur est gros.

this smoker is fat

Concerning another adjective that behaves in a similar way to "gros", we consider the case of "petit" ("small"). It is important to note that the adjective "gros" can be replaced by its antonym, "petit", to obtain the opposite reading. Hence, "un petit fumeur" will denote a person who smokes only a little, "un petit dormeur" a person who sleeps only a little, and so on. "Petit" is also interpreted intersectively in a postnominal position: "un petit fumeur" describes a smoker of short height.

It should be noted that there is a correlation between the adjective "gros" and the adverb "beaucoup" in all of the non-intersective examples. As a matter of fact, the sentences in (12) and (13) convey the same meaning.

(12) C'est un gros fumeur.

it-is a GROS smoker

'He's a heavy smoker.'
(13) Il fume beaucoup.

he smokes lot

'He smokes a lot.'

The non-intersective interpretation of "gros" seems to be quite systematic. A corpus research from two French corpora (CFPP200 and ESLO1/2, see Branca-Rosoff et al. 2012; and Eshkol-Taravella et al. 2011, respectively) has demonstrated several other uses of the adjective "gros" with -eur deverbal nouns, where the interpretation is always non-intersective for a prenominal adjective: "gros gapsilleur" ("big wasteful person"), "gros utilisateur de X" ("big user of X"), "gros lecteur" ("big reader"), "gros acheteur" ("big buyer"), "gros fournisseur" ("big supplier"), and "gros transporteur" ("big transporter").

\subsection{Generalisations and Goals}

On the basis of the data discussed in the previous section, I derive the following generalisations for French concerning adjectives in the same category as "gros":

1. Intersective adjectives can surface in different positions when used attributively (prenominal or postnominal).

2. Non-intersective adjectives always occupy a specific position in the structure.

3. In a predicative position, the adjective always receives an intersective interpretation.

Now that I have introduced these generalisations, the goals that I aim to achieve in this paper are listed below.

1. To observe the interaction of French -eur nominals with ambiguous adjectives.

2. To give a compositional analysis of the phenomenon.

3. In the literature, the discussion about ambiguous adjectives focused on deciding which part of the DP was responsible for the ambiguity: "Blame AP" (Siegel 1976; Despić and Sharvit 2008) or "Blame NP" (Larson 1998). I will argue in favor of a third possibility which is necessary to capture the ambiguity: "Blame both". 
Before presenting my analysis of ambiguous adjectives in French, I will discuss three analyses that have been proposed in the literature to account for similar data.

\section{PREVIOUS ANALYSES OF AMBIGUOUS ADJECTIVES}

In this section, I will first discuss the conflicting views of Siegel (1976) and Larson (1998) about adjectival ambiguity. The former advocates for an A-analysis, where the ambiguity results from the adjective only, while the latter proposes that an analysis in which the noun is responsible for the ambiguity is more plausible ( $\mathrm{N}$-analysis).

\subsection{Larson vs. Siegel}

In the literature, many researchers have provided accounts of the ambiguity present in the sentence in (14).

Olga is a beautiful dancer.

This sentence can be interpreted in an intersective manner, where what the speaker wants to convey is that Olga is both a dancer and a beautiful person. However, it also bears a non-intersective reading, where the meaning of the sentence is that Olga is beautiful as a dancer. In her dissertation, Siegel proposed a theory that could explain the ambiguity of (14), which has both an intersective and a non-intersective reading. ${ }^{2}$ Siegel based her analysis on the fact that in Russian, the morphology of adjectives is such that they can appear in two different forms: one that is intersective only (the shortform) and another that is non-intersective (the long-form). This observation leads her to suggest that the adjective category - which has been considered to bring together every adjective - is to be conceived of as two separated classes of items that are syntactically and semantically distinct.

1. The first class contains adjectives that only appear in the predicative position, and are extensional and intersective, such as aged.

2. The second class contains adjectives that appear in the attributive or predicative position, and are intensional and non-intersective, such as former.

Siegel believes that this classification sheds light on the problem of adjectival ambiguity: while some adjectives appear only in one of these two classes, but not in the other (like aged or former), others like beautiful exist in two forms that are homophonous: one being in the first class, while the other is in the second class. In her dissertation, Siegel calls adjectives of this kind doublets.

From this assumption, the doublet theory for adjectives suggests that when two forms exist, one has an intersective semantic value, and the other a non-intersective

2 Unfortunately, I did not have access to Siegel's original document while writing this paper, thus the way her proposal is presented here is taken from indirect sources such as Larson (1998) and Morzycki (2013). 
semantic value. This explains the data from English (for example, the sentence in (14)), in which ambiguity is due to the existence of two lexical entries for homophonous adjectives.

Contrary to Siegel, Larson (1998) develops a theory in which the ambiguity of the adjective beautiful in (14) is not due to the complexity of the adjective, but results more from the lexical properties of the noun it modifies (the so called $N$-analysis). In his analysis, Larson assumes that deverbal nouns like dancer involve event structure and a genericity operator. This analysis is based on the observation that a noun like dancer can be considered as derived from the verb to dance. According to Larson, at least in this structure, the verb to dance denotes the set of events of dancing. ${ }^{3}$ Since the noun dancer possesses some event-structure, it can refer to an individual who habitually participates in an event of dancing. To achieve this, Larson postulates the presence of a genericity operator. The main point of this proposal is that, in a first step of the derivation, the noun dancer denotes sets of events, and, in a second step, it is combined with the GEN-operator, denoting sets of individuals at the end.

With this assumption, it is straightforward to account for the ambiguity of the adjective beautiful in the sentence Olga is a beautiful dancer: the adjective can either modify the event argument of the noun, giving rise to the non-intersective reading ("Olga dances beautifully"), or modify the individual argument of the noun (once the GEN-operator has applied) to give rise to the intersective reading ("Olga is a dancer and Olga is beautiful").

Larson claims that this theory is an $N$-analysis, since he demonstrates that it is the complex structure of the noun that is responsible for the ambiguity of the sentence, and thus this ambiguity is supposed to be structural (as opposed to Siegel's analysis that advocated for a lexical ambiguity).

\subsection{Winter and Zwarts}

In this last part of section 2, I present the theory proposed by (Winter and Zwarts 2012a,b) (henceforth W\&Z), in which Larson's proposal is further developed. Larson did not present a clear compositional theory in his paper, a gap that $\mathrm{W} \& \mathrm{Z}$ propose to fill.

$W \& Z$ introduce an operator that allows for the saturation of the event variable of a deverbal noun like dancer. During the derivation, the verb dance is first generated with type $<\mathrm{v}$,et $>$. The role of the -er morpheme is only morphological: it turns this verb into a noun syntactically. This morpheme is semantically vacuous: its semantic value can be seen as an identity function that takes a two-place predicate of type $<\mathrm{v}$,et $>$ and results in the same kind of predicate (see (15)).

$$
[[-e r]]=\lambda P_{<v, e \triangleright\rangle} \cdot P
$$

At this point, semantically dancer looks like a verb, since the event argument is still present (at this step of the derivation, the authors represent this category as NPer,

3 I will associate the type $\mathrm{v}$ to event arguments. 
meaning that this constituent behaves syntactically like a noun, but that its event argument is not yet saturated).

W\&Z assume, in a manner similar to Larson, that there is a covert operator (SAT) that saturates the event argument of the NPer, transforming it into a predicate of individuals (of type $<\mathrm{e}, \mathrm{t}>$ ). This operator has a semantic value similar to that of the GENoperator used by Larson.

(16) $[[S A T]]=\lambda P_{<v, e \triangleright} \cdot \lambda x_{e .} \exists \mathrm{E}[P(x)(\mathrm{E}) \wedge[x$ habitually participates in $P$-events $]]$

(17) demonstrates the derivation of the DP the beautiful dancer - on its non-intersective reading - and its semantic composition.

(17) The beautiful dancer

a)

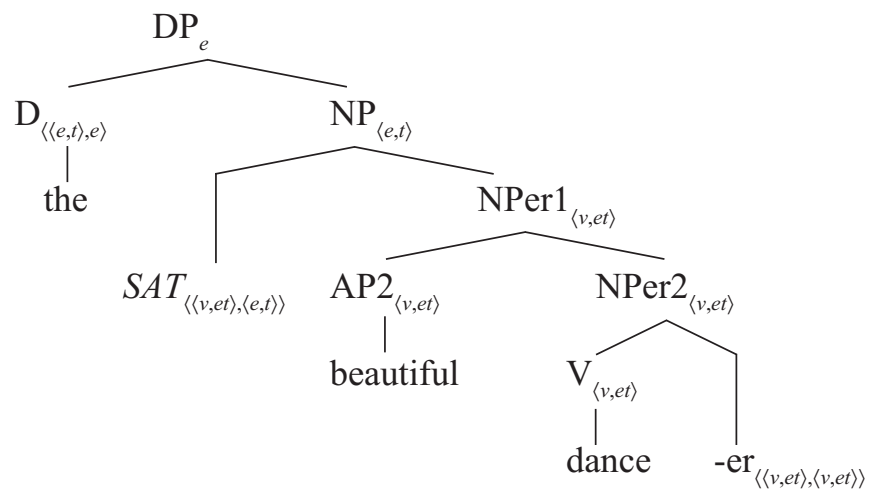

b) $[[-$ er $]]=\lambda P_{\langle v, e \triangleright} \cdot P$

$[[$ dance $]]=\lambda \mathrm{Ev} . \lambda x_{e .}[$ dance $(\mathrm{E}) \wedge \operatorname{ag}(\mathrm{E})=x]$

$[[$ NPer1 $]]=\lambda \mathrm{Ev} \cdot \lambda x_{e}[$ dance $(\mathrm{E}) \wedge \operatorname{ag}(\mathrm{E})=x \wedge$ beautiful(E) $]$

$[[\mathrm{SAT}]]=\lambda P_{<v, e \triangleright} . \lambda x_{e .} \exists \mathrm{E}[P(x)(\mathrm{E}) \wedge[x$ habitually participates in $P$-events $]]$

$[[\mathrm{NP}]]=\lambda x_{e}$. $[$ dance $(\mathrm{E}) \wedge \operatorname{ag}(\mathrm{E})=x \wedge$ beautiful $(\mathrm{E}) \wedge[x$ habitually participates in dancing-events]]

Even though W\&Z's proposal improved what Larson proposed by giving a more detailed compositional analysis of ambiguous DPs, I believe that the generic operator in their structure is not precise enough. As a matter of fact, according to both Larson and W\&Z, the denotation of a NP like "fumeur" should be along the lines of the one in (18).

$$
[[\text { fumeur }]]=\lambda x_{\text {e. }} x \text { usually/habitually smokes. }
$$

It seems to me that describing a smoker by saying that he or she "habitually" smokes is not precise enough. For example, if someone smokes every 1st of January, it seems 
habitual for this person to do so, but it does not mean that she/he is a smoker. I will thus build on W\&Z's account for my own analysis, but I will attempt to give a more precise semantics to the deverbal noun "fumeur", and I will provide a more articulated analysis for the operator, corresponding to the generic operator used by Larson and W\&Z.

\section{ANALYSIS}

In this analysis, I will follow Winter and Zwarts (2012a,b), who argue that a decompositional analysis of deverbal nouns is necessary. Deverbal nouns contain a verbal root that denotes a set of events and an operator, EUR, whose semantic contribution is to take a predicate of events and give back a predicate of individuals, specifying the agent. This operator saturates the event argument contained in the verbal root. There are two possibilities for accounting for the fact that the positions of the operator EUR and the morphological -eur (semantically vacuous) are distinct:

1. Either there are two different positions, and the morpheme -eur is licensed by the presence of a covert operator, EUR.

2. Or there is only one element that appears higher than the verbal root at LF, and a spell-out rule specifies that this element must attach itself with the verbal root at PF.

In the semantics of the EUR -operator, I will make use of the concept of situations (see Kratzer 2004). A person will qualify as a smoker if he or she has a high chance of lighting a cigar/cigarette/... when he or she is allowed to, is able to, and wants to smoke. Thus, I propose that we can quantify over situations to obtain this kind of meaning. The denotation of a NP like "fumeur" is as in (19), and that of the EUR-operator is in (20).

$$
\begin{aligned}
{[[\text { smoker }]]=} & \lambda x_{\mathrm{e}} \cdot \operatorname{MOST}(s)[s \text { is a situation in which the conditions for } x \text { to } \\
& \text { smoke } \operatorname{are} \operatorname{good}, \exists \mathrm{E}[\mathrm{E} \in S \wedge \mathbf{s m o k e}(\mathrm{E}) \wedge \mathbf{a g}(\mathrm{E})=x]] \\
= & \lambda P_{<v, \triangleright} \cdot \lambda x_{\mathrm{e}} \cdot \operatorname{MOST}(s)[s \text { is a situation in which the conditions } \\
& \text { for } x \text { to } P \text { are good, } \exists \mathrm{E}[\mathrm{E} \in s \wedge P(\mathrm{E}) \wedge \mathbf{a g}(\mathrm{E})=x]]
\end{aligned}
$$

Concerning the semantics of the adjective "gros" under its non-intersective reading, I will adopt the i-sum operator defined by Link (1983). I claim that the denotation for the non-intersective reading should modify the event argument present in the verbal root, taking a two-place predicate of simple atomic events (of type $\langle\mathrm{v}, \mathrm{t}\rangle$ ), and giving back a predicate of complex events themselves constituted of atomic events (also of type $<\mathrm{v}, \mathrm{t}>$ ). The denotation for the non-intersective version of "gros" is given below.

$$
\begin{aligned}
{\left[\left[\operatorname{gros}_{1}\right]\right]=} & \lambda P_{<v, \triangleright} \cdot \lambda \mathrm{E}_{v} \cdot \text { E is constructed via } \oplus \text { from many atomic events } \\
& \text { that are non-overlapping in } P(\mathrm{E})
\end{aligned}
$$

With this kind of semantic value for the non-intersective "gros", a DP like "un gros fumeur" will denote someone who participates in many events of smoking when the 
conditions for him or her are good to do so. This pairs well with the fact that a sentence containing the adverb "beaucoup" conveys the same meaning as one containing the adjective and the noun (examples (12) and (13) from section 1 are repeated below as (22) and (23)).

(22) C'est un gros fumeur. it-is a GROS smoker "He's a heavy smoker."
(23) Il fume beaucoup. he smokes lot "He smokes a lot."

\subsection{Prenominal Position: Non-Intersective Reading}

Now that all the ingredients necessary for my analysis are introduced, let us consider how to derive the non-intersective interpretation of a DP containing a deverbal noun and the adjective "gros" in prenominal position.

The adjective, being of type $<\mathrm{v}, \mathrm{t}>$, will apply to the verbal root fum- before the EURoperator is inserted into the structure. The structure and the semantic composition of "gros fumeur" are shown below.

a)

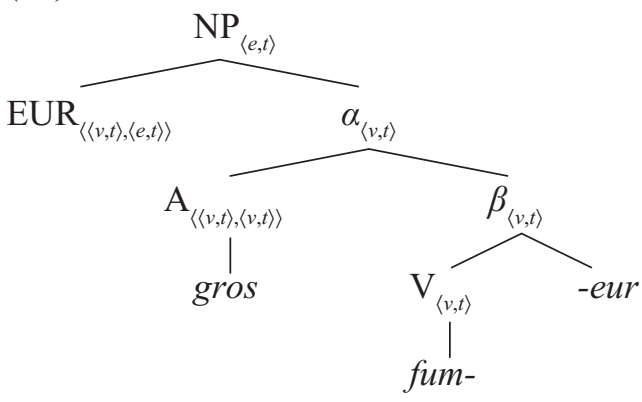

b) $[[\beta]]=\lambda_{\mathrm{E}_{v}}$. smoke(E)

$[[\mathrm{A}]]=\lambda P_{\langle\nu, \triangleright} \cdot \lambda \mathrm{E}_{v^{\prime}}$ E is constructed via $\oplus$ from many atomic events that are nonoverlapping in $P(\mathrm{E})$

$[[\alpha]]=\lambda \mathrm{E}_{v}$. $\mathrm{E}$ is constructed via $\oplus$ from many atomic events that are non-overlapping in $\{\mathrm{E}$ : $\operatorname{smoke}(\mathrm{E})\}$

$[[\mathrm{NP}]]=\lambda x_{\mathrm{e}} \cdot \operatorname{MOST}(s)[s$ is a situation in which the conditions for $x$ to smoke are good, $\exists \mathrm{E}[\mathrm{E} \in S \wedge \mathrm{E}$ is constructed via $\oplus$ from many atomic events that are non-overlapping in $\{\mathrm{E}: \operatorname{smoke}(\mathrm{E})\} \wedge \mathbf{a g}(\mathrm{E})=x]]$

\subsection{Prenominal and Postnominal Position: Intersective Reading}

Concerning the postnominal position of the adjective "gros", which only gives rise to an intersective reading, and the prenominal position, where it is also possible (even if 
dispreferred) to have an intersective reading, I propose that the adjective has a different semantic value. This second version of the adjective is simpler, since it only denotes an individual property, as shown in (25).

$$
\left[\left[\operatorname{gros}_{2}\right]\right]=\lambda x_{\mathrm{e}} \cdot x \text { is fat }
$$

This adjective cannot modify a predicate of events such as the verbal root fum-, since it does not bear any event argument in its semantic value. The only option for applying it is after the combination of the verbal root and the EUR-operator. This gives rise to the intersective reading, as expected (consider (26) for the postnominal position, and (27) for the prenominal position with an intersective reading ${ }^{4}$ ).

a)

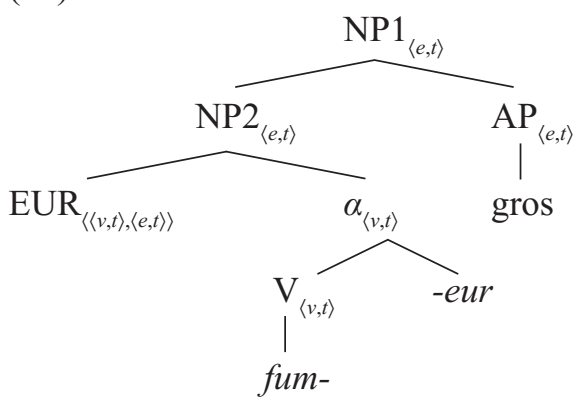

b) $[[\mathrm{NP} 2]]=\lambda x_{\mathrm{e}} \cdot \operatorname{MOST}(s)[s$ is a situation in which the conditions for $x$ to smoke are good, $\exists \mathrm{E}[\mathrm{E} \in S \wedge \mathbf{s m o k e}(\mathrm{E}) \wedge \mathbf{a g}(\mathrm{E})=x]]$

$[[\mathrm{AP}]]=\lambda x_{\mathrm{e}} \cdot \mathbf{f a t}(x)$

$[[\mathrm{NP} 1]]=\lambda x_{\mathrm{e}} \cdot \operatorname{MOST}(s)[s$ is a situation in which the conditions for $x$ to smoke are $\operatorname{good}, \exists \mathrm{E}[\mathrm{E} \in S \wedge \mathbf{s m o k e}(\mathrm{E}) \wedge \mathbf{a g}(\mathrm{E})=x] \wedge \mathbf{f a t}(x)]$

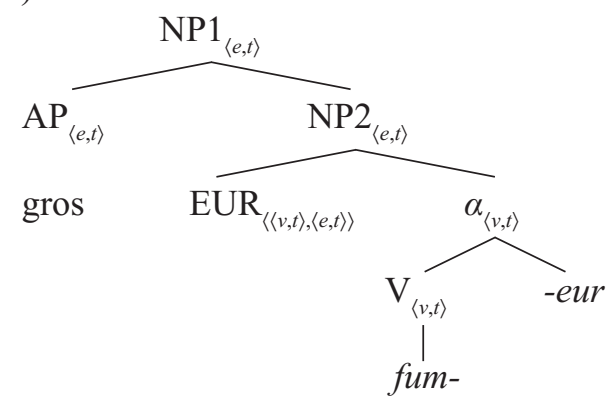

4 For (27), the details of the semantic composition are not given, since they are the same as the ones for (26). 
At this point, we must find a way to prevent a structure like the one in (28), where the adjective is postnominal and at the same time within the scope of the operator.

$$
\left[_{\mathrm{NP}} \operatorname{EUR}\left[\left[\left[_{\mathrm{V}} \text { fum- }\right][\text {-eur }]\right] \text { gros }\right]\right]
$$

In order to avoid these structures, I postulate the existence of a reduced relative clause in the case of postnominal adjectives, in a manner similar to that of (Cinque 2010):

(29) Un fumeur (qui est) gros

a smoker (who is) fat

In this way, the postnominal adjective can never be within the scope of the operator, and is not required to have access to the event argument inside the verbal root. Contrary to previous analyses in which the ambiguity of a DP like a beautiful dancer or "un gros fumeur" was either due to the complexity of the adjective (A-analysis, or "blame $A P$ ") or that of the noun ( $N$-analysis, or "blame $N P$ "), the present proposal claims that this ambiguity is due both to the semantics of the deverbal noun and the presence of two lexical entries for the relevant ambiguous adjective ("blame both"). This claim supports the fact that an adjective in the same category as "gros" - one that has actually two different meanings - cannot be used ambiguously with every type of noun. As an example, in (30), the noun "porte" ("door") does not bear any event structure. Thus, the adjective "gros" can only be used intersectively with this noun.

(30) Une grosse porte

a GROS.fem door

This demonstrates that the ambiguity of the adjective is not sufficient to create an ambiguity at the NP-level, and that a "blame both" type of analysis is on the right track. $^{5}$

\subsection{Bracketing Paradoxes}

As W\&Z (see 2012b: 642) emphasise, the kind of analysis proposed here raises the problem of what has been referred to as "bracketing paradoxes" in the literature. Namely, we need the adjective "gros" to apply to the root "fum-" before the semantically covert EUR applies. It should be useful to consider the analysis of rebracketing (Spencer 1988) to avoid this kind of problem (see examples (31) and (32)).

5 It is nonetheless possible that other nouns that are not -eur deverbal nouns can also combine with intersective and non-intersective versions of the adjective "gros". In this case, we could imagine that this kind of noun also has some kind of complex structure (even if it is not morphologically visible), and that the two versions of the adjective modify the noun at different positions in this structure. 
(31) a. Uneasier: [un- [easi- -er]] $\Rightarrow$ [[un- easi-] -er]

b. Nuclear physicist: [nuclear [physics- -ist] $\Rightarrow$ [[nuclear physics-] -ist]

(32) Gros fumeur: [gros [fum- -eur] $\Rightarrow[$ [gros fum-] -eur]

\subsection{Unifying the Two Lexical Entries for "gros"}

In the analysis defended here ("blame both"), two different lexical entries for the adjective "gros" are required. However, intuitively, it seems a good idea to attempt to unify the two readings of the adjective. To do so, we can imagine an alternative semantics.

In this analysis, the type of the adjective is $\langle\langle\sigma, t\rangle,\langle\sigma, t\rangle\rangle$, where $\sigma$ denotes the union of the domain of entities and the domain of events: $\sigma=D_{e} \cup D_{v}$

If we consider that there is a type $\sigma$ that can denote both events and individuals, we can make use of partial functions to avoid problems:

(33) a. $\lambda x_{\sigma}: x$ is an event. $x \ldots$

b. $\lambda x_{\sigma}: x$ is an individual. $x \ldots$

In this case, the two versions of "gros" would have an identical type. Their meaning, however, is not related in any sense. To connect the two meanings, a possibility would be to do so inside the lexicon. This can be made possible in a generative lexicon framework, such as the one developed in Pustejovsky (1995). Since developing an account combining my analysis and the framework developed by Pustejovsky would go beyond the scope of this paper, I will leave this for further research (however, see also McNally (2005) for a similar argument).

\section{CONCLUSION}

In this study, I aim to give an account of adjectival ambiguity with deverbal nouns in French. I claim that the adjective "gros" is ambiguous between two different readings, one intersective and the other non-intersective. However, the ambiguity of these constructions is also due to the presence of an operator inside deverbal nouns. The scope of this operator defines where the intersective and non-intersective adjectives can apply.

An interesting development of the analysis developed here has to do with episodicity and genericity. It seems that the non-intersective reading of a complex NP containing the prenominal adjective gros and an -eur deverbal noun is correlated with the possibility of having an episodic reading of the deverbal noun (vs. a generic one). For someone to be "un fumeur", this person must have been involved in episodic events of smoking.

Another kind of deverbal nouns, namely, instrumentals, do not follow the same logic. "Un aspirateur" (a vacuum-cleaner) is an object the purpose of which is to "aspirer", but even if it has never been involved in an episodic event of "aspirer", it is nonetheless referred to as "un aspirateur".

What is interesting is that contrary to episodic deverbal nouns such as "fumeur", non-episodic deverbal nouns do not give rise to a non-intersective reading when combined with the adjective "gros": "un gros aspirateur" is not something that "vacuums 
up a lot", but an object that is big (see Roy and Soare 2014 for more details). This would need to be accounted for in the type of analysis presented here. There should be a difference in the semantics of deverbal nouns such as "fumeur", and instrumentals such as "aspirateur", that concerns the contribution of the EUR operator.

\section{References}

BRANCA-ROSOFF, Sonia/Serge FLEURY/Florence LEFEUVRE/Mat PIRES (2012) Discours sur la Ville. Présentation du Corpus de Français Parlé Parisien des Années 2000 (CFPP2000). http://cfpp2000.univ-paris3.fr/CFPP2000.pdf.

CINQUE, Guglielmo (2010) The Syntax of Adjectives: A Comparative Study. Cambridge, MA: MIT Press.

DESPIĆ, Miloje/Yael SHARVIT (2008) "Some "Non-Intersective" Adjectives are Truly Non-Intersective." In: S. Lima/K. Mullin/B. Smith (eds), Proceedings of North Eastern Linguistic Society 39. Amherst: GLSA, 281-294.

ESHKOL -TARAVELLA, Iris/Olivier BAUDE/Denis MAUREL/Linda HRIBA/Celine DUGUA/Isabelle TELLIER (2011) Un Grand Corpus Oral "Disponible": Le Corpus d'Orléans 1968-2012. http://eslo.huma-num.fr/.

KAMP, Hans/Barbara Hall PARTEE (1995) "Prototype Theory and Compositionality." Cognition 57/2, 129-191.

KRATZER, Angelika (2004) "Covert Quantifier Restrictions in Natural Languages." Lecture from Milan Meeting, Palazzo Feltrinelli (Gargnano).

LARSON, Richard K. (1998) "Events and Modification in Nominals." In: D. Strolovitch/L. Lawson (eds), Proceedings from Semantics and Linguistic Theory (SALT) VIII. Ithaca, NY: Cornell University, 145-168.

LINK, Godehard (1983) "The Logical Analysis of Plurals and Mass Terms: A LatticeTheoretical Approach.” In: R. Bäuerle/C. Schwarze/A. von Stechow (eds), Meaning, Use and Interpretation of Language. Berlin, Germany: De Gruyter.

MCNALLY, Louise (2005) "Lexical Representation and Modification within the Noun Phrase." Recherches Linguistiques de Vincennes 34, 191-206.

MORZYCKI, Marcin (2013) "The Lexical Semantics of Adjectives: More Than Just Scales.” Ms., Michigan State University. https://msu.edu/ morzycki/work/papers/ chapter_notscales.pdf

PARTEE, Barbara Hall (1995) "Lexical Semantics and Compositionality.” In: D. Osherson (ed.), Invitation to Cognitive Science. Cambridge, MA: MIT Press, 311-360.

PARTEE, Barbara Hall (2010) "Privative Adjectives: Subsective Plus Coercion." In: R. Bäuerle/U. Reyle/T. E. Zimmermann (eds), Presuppositions and Discourse: Essays Offered to Hans Kamp. Bingley, UK: Emerald Group Publishing, 273-285.

PUSTEJOVSKY, James (1995) The Generative Lexicon. Cambridge, MA: MIT Press. ROY, Isabelle/Elena SOARE (2014) "On the Internal Eventive Properties of -er Nominals." Lingua 141, 139-156.

SIEGEL, Muffy Emily Ann (1976) Capturing the Adjective. Ph.D. Thesis. University of Massachusetts. 
SPENCER, Andrew (1988) "Bracketing Paradoxes and the English Lexicon." Language 64, 663-682.

WINTER, Yoad/Joost ZWARTS (2012a) "Event Orientated Adnominals and Compositionality." Unpublished Ms., to appear in Proceedings of Annual Meeting of the Israeli Association of Theoretical Linguistics, October 2012, Tel-Aviv.

WINTER, Yoad/Joost ZWARTS (2012b) "On the Event Semantics of Nominals and Adjectives - The One Argument Hypothesis." In: A. A. Guevara/A. Chernilovskaya/R. Nouwen (eds), Proceedings of Sinn und Bedeuntung 16. Cambridge, MA: MIT Working Papers in Linguistics, 639-645.

Summary

\section{AMBIGUOUS ADJECTIVES IN FRENCH: THE CASE OF “GROS” WHEN COMBINED WITH DEVERBAL NOUNS}

In this paper, I analysed the interaction between the French adjective "gros" and -eur deverbal nouns. This adjective gives rise to a preferred non-intersective reading when it is in a prenominal position, but only an intersective reading when it appears after the noun. I claim that it is necessary to take into account both the semantics of the adjective and the semantics of the noun to account for the ambiguity present at the DP-level (a "blame both" analysis). An abstract operator, EUR, is always present within deverbal nouns such as "fumeur" ("smoker"), and is partially responsible for the interpretation of the DP: if the adjective is within the scope of this operator, the DP will assume a non-intersective reading, whereas when it is outside of its scope, the DP bears an intersective interpretation. The adjective "gros" itself actually has two semantic values: one modifies the event argument present in deverbal nouns, and the other modifies the individual argument of the noun (the agent of the verbal root).

Keywords: adjectives, ambiguity, deverbal nouns, event semantics

Povzetek

\section{DVOUMNI PRIDEVNIKI V FRANCOŠČINI: PRIMER PRIDEVNIKA „VELIK“V KOMBINACIJI Z IZGLAGOLSKIMI SAMOSTALNIKI}

V članku je podana analiza interakcije med francoskim pridevnikom gros , velik‘ in izglagolskimi izpeljanimi samostalniki s pripono -eur. Pri tem pridevniku v položaju pred samostalniškim jedrom je najbolj pogosto nepresečno branje, medtem ko je v položaju za samostalnikom edino možno branje presečno. V članku zagovarjam trditev, da je za razlago dvoumnosti na nivoju določilniške zveze (DZ) potrebno upoštevati semantične lastnosti obeh, pridevnika in samostalnika. Pri izglagolskih samostalniških izpeljankah kot fumeur ,kadilec' je vedno prisoten abstraktni operator EUR, ki je delno odgovoren za interpretacijo DZ. Če je pridevnik v dosegu operatorja, bo DZ imela nepresečno branje, če pa je pridevnik izven dosega, bo DZ imela presečno branje. 
Pridevnik gros, velik‘ ima namreč dve semantični vrednosti: ena od njih modificira dogodek, ki je prisoten v izglagolskih samostalnikih, druga pa posamezni argument samostalnika (vršilec glagolskega dejanja v glagolskem korenu).

Ključne besede: pridevniki, dvoumnost, izglagolski samostalniki, dogodkovna semantika 